\title{
On the Re-Configurations of Cinematic Media-Spaces: From Diaspora Film to Postdiaspora Film
}

\author{
Alena Strohmaier
}

\section{Introduction ": "Diaspora is Highly Contemporary”}

"Whether 'diaspora' is a common word, a scientifically constructed concept, or a rallying cry that gives meaning to a collective reality, it is highly contemporary. Denying this would be pointless" (2008, p. 106), Stéphane Dufoix claims. The case of the Iranian diaspora and its filmmaking are particularly interesting objects of investigation because they illustrate the re-configurations of both diaspora into postdiaspora and diaspora film into postdiaspora film, revealing the contemporariness of the "diaspora" lens through its potential for accommodating transformation and change.

Iran, like most of today's nation-states, has a long history of migration. As early as the eighth century, Zoroastrians fled from Iran to neighboring India for religious freedom after the Arab-Muslim colonization. In the nineteenth century, many Iranians migrated to the neighboring czarist Russian Empire to work in the oil industry. After the Second World War, many Jewish Iranians emigrated to the newly founded state of Israel. In the second half of the twentieth century, many Iranians from the middle and upper social classes went to countries such as Germany, France, Britain, Austria, and the United States for higher education with the initial aim of bringing their newly acquired knowledge back to Iran (Raji 2010, p. 193). The year 1979, however, marked a turning point: the Islamic revolution, which resulted in the deposition of Shah Reza Pahlavi and the establishment of an Islamic republic under Ayatollah Khomeini, led to probably the largest

\footnotetext{
A. Strohmaier $(\bowtie)$

Institut für Medienwissenschaft/Centrum für Nah- und Mittelost Studien, Philipps-Universität Marburg, Marburg, Germany

e-mail: alena.strohmaier@staff.uni-marburg.de

(C) The Author(s) 2021

R. Ouaissa et al. (eds.), Re-Configurations, Politik und Gesellschaft des Nahen Ostens, https://doi.org/10.1007/978-3-658-31160-5_14
} 
wave of emigration the country has ever seen. The consequences of the Islamic revolution and the Iran-Iraq War prevented members of the first wave from returning to Iran. Further waves of migration followed in the 1990s and increased after the uprisings of the Green Movement in 2009. There are currently no comprehensive statistics on the total number of Iranians living outside Iran, but it is estimated to be between four and six million (Vahabi 2012). Most Iranians relocated to North America, closely followed by Europe and Australia, with major cities as primary destinations. Iranians also moved to business-friendly cities in the MENA region such as Istanbul, Doha, and Dubai.

This chapter is primarily concerned with the re-configuration of diaspora into postdiaspora fueled by the formation of the (self-applied) term "Iranian diaspora" and its cinematic representations in what are termed postdiaspora films. It makes three underlying theoretical assumptions: first, the development of a flexible and open concept of diaspora; second, an anti-essentialist definition of culture; and third, questioning of the dazzling category of the "hybrid." In a close analysis of Ana Lily Amirpour's 2014 film A Girl Walks Home Alone at Night, I will demonstrate that these re-configurations manifest on three spatial levels: the real space of the diaspora, which is subject to socio-political changes; the internal-diegetic spaces in the films themselves, which constantly bring new themes to the fore; and film as its own space-creating entity that constantly updates its own mediality. In postdiaspora films, these different spatial dimensions come together and convey new cinematic media-spaces.

\section{From Exile to Diaspora}

"How then has this group of religiously, ethnically, and linguistically diverse people with different pasts constructed an Iranian identity in diaspora? Why is Iranian immigration even termed a diaspora?" (2003, p. 685), Nilou Mostofi asks. In order to answer this question, it is crucial to draw distinctions with other terms in the context of migration. The (self-applied) label of Iranians living abroad as "diasporic" or simply as "diaspora" is a recent development. In popular discourse as well as in research, the terms "refugee," "émigré," and "exile" were initially predominant, but this changed and Iranians "reinvented themselves as a distinct national and ethnic group outside of Iran. [...] A move away from the urgency of an exilic and immigrant narrative to one that situates Iran and Iranian culture in the continuum of more global diasporic consciousness" (Elahi and Karim 2011, p. 382 ff.). The Public Affairs Alliance of Iranian Americans claims: "Iranians are now at a point in their immigrant journey where they selectively choose elements 
of their Iranian and American identities, developing a unique 'diasporic' identity that is quite different from native Iranians" (2014, p. 11). Babak Elahi and Persis M. Karim also emphasize:

Iran's current diaspora is by necessity part of a longer continuous historical narrative in which Iranian peoples have adapted and reinvented themselves. It is not only the home culture that determines the direction of diaspora. Rather, the complex network of places and spaces of home and away are mutually transformative (2011, p. 387).

Hamid Dabashi's cultural studies research and Hamid Naficy's work on the TV and radio landscape of Los Angeles in 1993 made the most significant contributions to the designation of "Iranian diaspora." Hamid Dabashi's monograph Parviz Sayyad's Theater of Diaspora uses the term prominently in the very title. In his introduction, he speaks of intergenerational links between artists of Iranian origin, implying the inherent characteristic of community in the concept of diaspora (Sayyad and Dabashi 1993, p. xi). Hamid Naficy, for his part, elaborates on the state of liminality and in-betweenness, and thus, despite the word "exile" in the title of his monograph The Making of Exile Cultures, speaks of "an ethnic minority, not just an exilic community" and "hyphenated Iranian-Americans and not just Iranians" (1993, p. 196), and finally invokes "people in diaspora" (1993, p. 16 f.). In his monograph An Accented Cinema: Exilic and Diasporic Filmmaking, published in 2001, he further differentiated sharply between exile and diaspora: "There is nothing common about exile and diaspora" (p. 3). Hamid Dabashi also stresses this point by deconstructing the concept of exile, which occupies a central place in the experience and life reality of people living outside Iran, especially those in Los Angeles. According to him, the repeated term "exile" fuels a narrative that reinforces binary opposites instead of dissolving them. He unmasks the narrative of exile as a construct when he finally argues that the majority of people living outside Iran are, strictly speaking, in a diaspora rather than in exile:

The fact is that with few exceptions the overwhelming majority of Iranians living outside Iran can get on an airplane and return to their homeland and there lead a half-decent life not particularly worse or better than what they lead in Los Angeles, Washington DC, London, or Paris (2009, p. 251).

In 2012, Hamid Naficy dedicated an entire volume of his four-volume monograph A Social History of Iranian Cinema to the Iranian diaspora and its filmmaking. Here, the concept of diaspora is omnipresent: he writes of "Iranian culture in the diaspora" (2012, p. 384) and of a "worldwide diaspora" (2012, p. 372), and uses the term in a clearly positive way:

Millions of Iranians are living outside their homeland in one of the greatest modern diasporas, from where they are creating dynamically intertwined multilat- 
eral, transnational, and multicultural communities tied to each other and to their homelands by a globaI mediawork (2012, p. 511).

In his opinion, the difference between "exile" and "diaspora" lies in the reference point or frame of reference: "exile" would tie it closely to the country of origin, Iran, whereas "diaspora" means the opening towards the current center of life and the coexistence of different influences:

While the exiles' identity involved a near exclusive, vertical relationship with the Iranian homeland, diasporic consciousness was multisited and multilateral: a vertical relationship with Iran and horizontal relations both with Iranian compatriot communities elsewhere and with their coethnics and coreligionists across the globe (2012, p. 395).

Similar to Dabashi, he also argues that the change from "exile" to "diaspora" has to do with the practical possibilities of return: "Finally, as exile became diaspora and immigration, and as more Iranians returned home for visits, the sights and sounds of home of decades earlier lost their hold" (2012, p. 388).

The shift from the terms "refugee," "émigré," and "exile" to "diaspora" should be seen in the context of the expansion of the concept of diaspora and the concomitant Diaspora Studies. It follows the change from a negative concept of a specific form of dispersion to a flexible and positive concept of global migration (Brah 1996; Bauböck 2010; Tölölyan 2012). The Iranian diaspora, like any diaspora, is by no means a coherent community, it includes people of different political colors, social origins and generations. A problematic aspect of the term "Iranian diaspora" is the adjective, which makes the ethnic attribution visible and thus follows a logic of inclusion or exclusion. The Dictionary of Ethnology describes ethnicity as a concept of a group of people with a uniform culture and identity (Streck 2000, p. 53). In his text "Old and New Identities, Old and New Ethnicities," Stuart Hall counters this all too simple, long-prevailing definition with the following:

They [ethnicities] are not already-produced stabilities and totalities in the world. They do not operate like totalities. If they have a relationship to our identities, cultural and individual, they do not any longer have that suturing, structuring, or stabilizing force, so that we can know what we are simply by adding up the sum of our positions in relation to them (2007, p. 45).

Closely tied to the concept of identity as a never-completed process, Hall conceptualizes ethnicity as an entity that is not self-contained either. The process from identity to ethnic identity, according to him, passes through identification and inclusion or exclusion mechanisms. These mechanisms play an important role, especially in the search for identity-forming narratives: 
In the course of the search for roots, one discovered not only where one came from, one began to speak the language of that which is home in the genuine sense, that other crucial moment which is the recovery of lost histories. The histories that have never been told about ourselves that we could not learn in schools, that were not in any books, and that we had to recover (2007, p. 52).

These narratives form the awareness of belonging and (self-)attributions. Stuart Hall cites the example of Jamaican people who, when asked whether they would describe themselves as "black," initially reacted with disbelief. The different shades of brown and black were anchored in Jamaican parlance by many different terms, but there was no single category. This only emerged during post-colonialism, as empowerment and demarcation from the white colonial powers. Stuart Hall therefore describes the category of "black" as follows: "Black was created as a political category in a certain historical moment. It was created as a consequence of certain symbolic and ideological struggles" (Hall 2007, p. 54). "Black" is thus a category that creates an ethnic attribution at a certain historical moment in a certain geographical place. What is made visible in an act of inclusion or exclusion is primarily a power relationship, a valorization or empowerment vis-à-vis the Other:

This notion breaks down the boundaries, between outside and inside, between those who belong and those who do not, between those whose histories have been written and those whose histories they have depended on but whose histories cannot be spoken (Hall 2007, p. 48).

Drawing on Stuart Hall, I would like to argue that the term "Iranian diaspora"-like the category of "black"-is a constructed category that stems from a specific socio-political and historical context. Taking the Islamic Revolution and the waves of migration associated with it as a starting point, the term is charged with the desire to describe the migratory condition in a positive way. Associated with this is the image of the well-integrated, left-wing, anti-religious, educated, and Western-oriented people of the middle to upper-middle classes, who are globally connected with Iran as well as with all other people within the Iranian diaspora and their respective countries. This carries the illusion of a homogeneous identity, which has been viewed critically:

The enemy had to be what we called "multi-culturalism." [...] Nobody would talk about racism but they were perfectly prepared to have "International Evenings," when we would all come and cook our native dishes, sing our own native songs and appear in our own native costume (Hall 2007, p. 55 f.).

In this sense, the term "Iranian diaspora" is not only symptomatic of a positive description of a certain experience and lived reality of people residing outside 
Iran in a certain historical and geographical context. Ethnicity is used here as a definite means of cultural localization; "of positioning, of placing [that] the term ethnicity connotes" (Hall 2007, p. 61). Cultural localization is always tied up with identity, because, according to Stuart Hall, it takes place within representation itself, not outside it: "Identity is always in part a narrative, always in part a kind of representation. It is always within representation. Identity is not something which is formed outside and then we tell stories about it" (2007, p. 49).

The term "Iranian diasporic cinema," like "Iranian diaspora," also carries the ethnic attribution as a marker of positioning within a cultural field, in this case film. This approach assumes that such positions are always reached through processes of negotiation and delimitation: "The fact remains that every new position, in asserting itself as such, determines a displacement of the whole structure and that, by the logic of action and reaction, it leads to all sorts of changes in the prises de position of the occupants of the other positions" (Bourdieu 1983, p. 338; emphasis in original).

In the following analysis of Ana Lily Amirpour's A Girl Walks Home Alone At Night, I will show that "Iranian diasporic cinema" is centrally concerned with the dissolution of cultural and generic ascriptions, leading to a new form of cinematic media-space in which postdiasporic conditions are negotiated.

\section{Beyond Hybridity}

In most films of the Iranian diaspora from the 1980s and 1990s, the narrative themes of migration and travel are embedded in transitional spaces such as hotels and airports. Some early diasporic films that are popular for such scenes are Sarhad (Checkpoint), directed by Parviz Sayyad (USA, 1982); The Suitors, directed by Ghassem Ebrahimian (USA, 1988); Guests of Hotel Astoria, directed by Reza Allamehzadeh (USA, 1989); I Love Vienna, directed by Houshang Allahyari (Austria, 1991); and I Don't Hate Las Vegas Anymore (USA, 1994), directed by Caveh Zahedi.

The imaginary city of "Shahr-i Bad," depicted in the 2014 film A Girl Walks Home Alone at Night, poses an interesting example of transitional spaces other than airports and hotels. Ana Lily Amirpour started a crowdfunding initiative to fund her directorial debut, which premiered at the Sundance Film Festival in 2014. The story goes as follows: Arash (Arash Marandi) lives with his heroin-addicted father, Hossein (Marshall Manesh). They are harassed by a cruel, drug-dealing pimp named Saeed (Dominic Rans), who seizes the young man's prized Ford Mustang as payment for the father's debts to him. In a crime 
of opportunity, Arash in turn steals a pair of diamond earrings from the wealthy young woman he works for, Shaydah (Rome Shadanloo). At night, Saeed comes across a strange young woman in a chador. "The Girl" (Sheila Vand) seduces Saeed and convinces him to take her back to his apartment, where she grows fangs and kills him; it turns out she is a vampire. As she leaves, she passes Arash, who has come to offer the earrings in exchange for his car. He finds Saeed dead, and takes back his car keys along with a suitcase of drugs and cash. Arash decides to sell the drugs, allowing him to quit his job working for Shaydah. Later, he attends a costume party at a nightclub dressed as Dracula. "The Girl" with the chador spends her time listening to music alone in her apartment, skateboarding, or bedeviling pedestrians by night until she comes across the lost Arash. He shows vulnerability and compassion, and she takes him to her home, where they listen to music and she resists the temptation of his neck. Meanwhile, suffering from heroin withdrawal, Hossein has an episode where he believes Arash's cat to be his dead wife. The following morning, Arash discovers Hossein's dead body. Distressed, he runs to the apartment of "The Girl" and begs her to run away with him. They drive off together into an undecided future.

The film is shot in black-and-white and opens with a medium close-up of Arash. He is wearing sunglasses and smoking while he leans up against a garden fence in a casual manner reminiscent of James Dean (Fig. 1). The tall wooden fence takes up the right three-quarters of the shot, leaving the protagonist the left quarter of the shot; in other words, the view of the surroundings is initially restricted. The camera holds the shot steady to show Arash waiting as the Western-style opening credits roll. The first shot recalls the beginning of Sergio

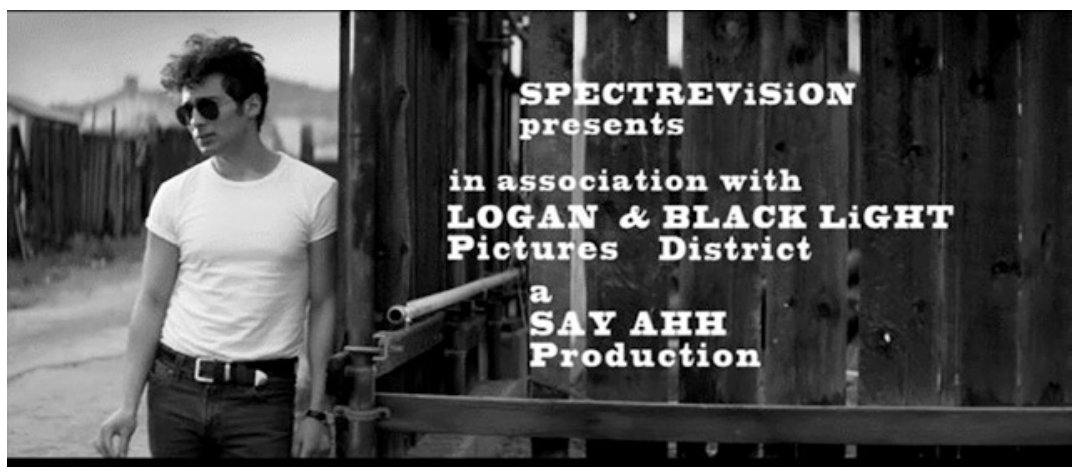

Fig. 1 A Girl Walks Home Alone at Night, “Opening," USA 2014 
Leone's 1968 Spaghetti Western Once Upon a Time in the West. Suddenly something seems to be moving behind the slits of the fence and Arash jumps through a gap to catch a cat. He then makes his way along the path as the camera follows his purposeful steps.

Slowly the camera pans out to reveal dusty streets, an empty parking lot, a large industrial building, and finally, in the background, the city. Arash continues to walk down the street with confidence as the camera shoots him from a birds-eye view. He walks past a street sign that reads "Shahr-i Bad" in Farsi, translating to "bad city" (Fig. 2). The camera pans out even further to a wide shot that reveals an American suburb, squeezed between the city and the rural landscape. The shot lacks any central area with a church, mosque, town hall, market, or square, and the view only shows a few houses of Shahr-i Bad (Fig. 3). It is impossible to identify the area from the shot geographically, but director Ana Lily Amirpour explains:

I think things that happen, happen inside me, and they happen in all the places in the world [...], which is loneliness, being misunderstood, wanting to find a connection, feeling isolated. I feel there is a heaviness that a lot of societies wear. And I don't really think it's a geographically specific thing (Amirpour 2015) ${ }^{2}$.

The street signs and the few spoken sentences in Farsi suggest that the story is set in Iran even though the film was shot in California. To the question if the director would have preferred shooting "on the actual locations," Amirpour responds:

I do think it's a fairytale and for me it's just an Iran of my mind. Film is an opportunity to make your own universe, make your own world. I think that's what is exciting and wonderful about it. [...] The great thing about art is that the limitations are actually the thing that encourages the creativity and push you to new places. I wanted to do this thing, ok so I cannot do it there, but then it became this limitless to really make my own place, make my own rules: we made the money,
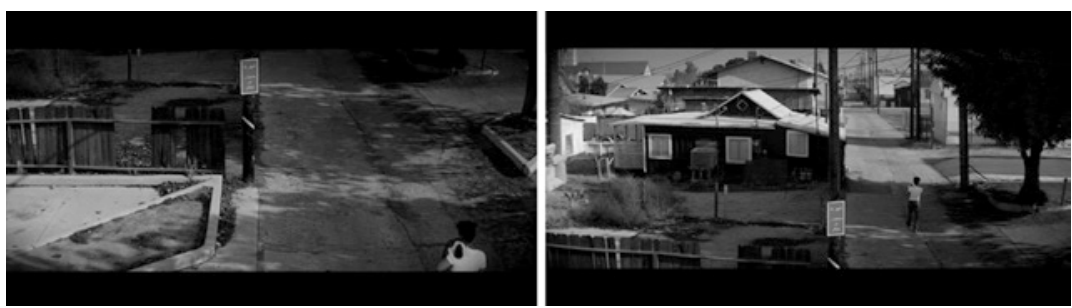

Fig. 2 and 3 A Girl Walks Home Alone at Night, "Arash enters the city," USA 2014 
we reinvented the posters, the street signs, it was like really glorious, like making a world, that's one of the best parts (Amirpour 2015) ${ }^{3}$.

Ana Lily Amirpour does not see resorting to made-up spaces as an involuntary or secondary solution due to the lack of real alternatives, but as a chance to open up and create new spaces through film. She has produced her own world, a no-man's-land, between the United States and Iran. Mixing elements from Iranian, American, and other (film) cultures links to Laura Marks' concept of intercultural cinema:

"Intercultural" indicates a context that cannot be confined to a single culture. It also suggests movement between one culture and another, thus implying the possibility of transformation. Intercultural means that a work is not the property of any single culture, but mediates in at least two directions. It accounts for the encounter between different cultural organizations of knowledge, which is one of the sources of intercultural cinema's synthesis of new forms of expression and new kinds of knowledge. (Marks 2000, p. 6 f.)

The transitional space of A Girl Walks Home Alone at Night is not a third space combining two or more elements (as conceptualized by Homi K. Bhabha); rather, it is the point of departure, the premise of the film. Shahr-i Bad is not only a transitional space because the tattooed and pierced drug dealer Saeed drinks black tea out of small Persian teacups, or because the chador-wearing protagonist listens to songs by the White Lies. It is a transitional space because there is a thin line between life and death, day and night, black and white, danger and comfort, and horror and humor. Shahr-i Bad is a fluid space constantly in motion and process, and most importantly, a space with cultural exchange and negotiation. The city goes beyond genre descriptions and reveals that diaspora is characterized by hybridity and not cultural essentialism. This hybridity appears in the transitional spaces of this film in a way that renders cultural designations impossible. Cultural and genre elements mix with imagined elements to the point that the construction is indicative of the relative arbitrariness of it all. In this sense Shahr-i Bad is a transcendent space, and so the dissolution of ethnic attributions coincides with the dissolution of genre attributions.

The vampire in A Girl Walks Home Alone at Night wears a chador that not only functions as camouflage, but as a nondescript look. In response to a question about reinterpreting the chador from a symbol of female repression to a rebellious vampire cloak, the director Ana Lily Amirpour says:

The chador has this weight, this velvety, satiny [texture], it catches the air in a certain way, it felt like really nice. The thing about the chador or any of the things we do, it could be the bumper stickers on your car, how you organize your house, all the things that make the system of how we appear in the world, the truth is that 

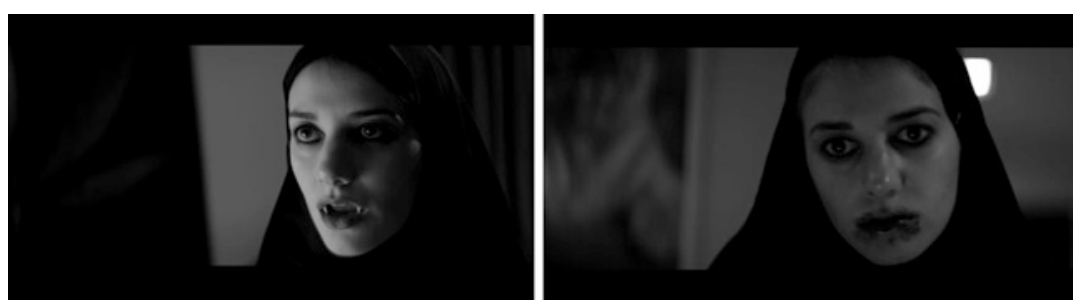

Fig. 4 and 5 A Girl Walks Home Alone at Night, "The vampire shows her teeth," USA 2014

Fig. 6 Only Lovers Left Alive, "Eve's bloodlust," USA 2013

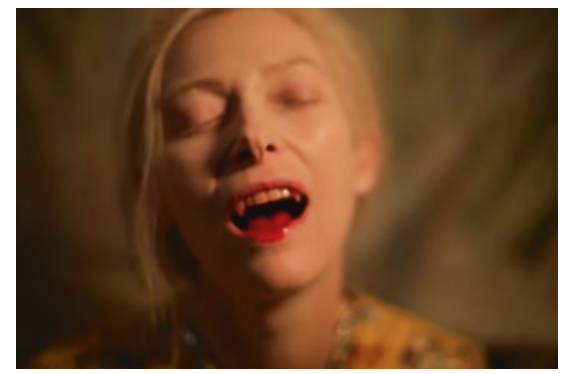

She does not see an ostensible political message in the use of the chador, but rather emphasizes the tactile and haptic dimension of the chador as a film prop.

"The Girl" is shown first in participating in everyday rituals like going for walks, putting on makeup, and listening to music. Only once she encounters the drug dealer Saeed, the camera zooms in on her face and reveals her pointy vampire fangs. She pounces on him and sucks his blood, after which the camera shows another close up of her face, her mouth smeared with blood and her eyes possessed with bloodlust (Fig. 4 and 5).

This closely parallels Jim Jarmusch's staging of his protagonist in the 2013 film Only Lovers Left Alive. After Eve (Tilda Swinton) drinks blood from a bottle for the first time, the camera zooms in on her face, showing her mouth covered in blood, her pointed teeth, and her eyes closed in a moment of pleasure (Fig. 6).

In both cases, the background becomes blurry and is no longer in the field of perception. The drug dealer's apartment in Shahr-i Bad and Eve's apartment in Tangier transcend into a new cinematic space of transformation. The woman 
believed to be human becomes a vampire and the film transitions into the alleged vampire film genre. The close-up in both scenes is purposely implemented as a cinematic tool of (de)visualization. In distanced shots, the viewer cannot recognize them as vampires. Only through the close-up do the traits of the vampire genre become visible in an over-exposition of blood and pointed teeth. The face becomes the cinematic space that reveals the genre.

In this "first Iranian vampire Western," the protagonists do not ride into the sunset on horses, extending the frontier and claiming newfound territory. However, Arash drives a Ford Mustang that exemplifies the frontier motif and is reminiscent of 1950s Americana; "The Girl" rides a skateboard that calls to mind the 1980s.

One scene shows an empty street lined with streetlights. In perfect symmetry with the shot, the vampire can be seen on the skateboard appearing in the distance (Fig. 7). She rides down the street towards the fixed camera before disappearing behind it, whipping her chador in the wind (Fig. 8).

The end of the film shows the Ford Mustang's headlights close up before zooming out to show the vampire and Arash sitting in the car with the cat between them, listening to music. After a long pause, the shot cuts to the back of the car as the lights go on and the engine starts. The lights illuminate the license plate that reads "Shahr-i Bad" in Farsi, thereby casting the city in focus one last time (Fig. 9). The Ford Mustang drives over the dusty desert road leaving behind the city and a small horizon of light at the top of the screen before finally disappearing in the darkness of the night (Fig. 10).

In both scenes, the shift from on to off screen, visible to invisible, by using alternating close ups and distance shots, becomes a crucial cinematic tool for conceptualizing the genre element of the frontier. In this sense, A Girl Walks Home
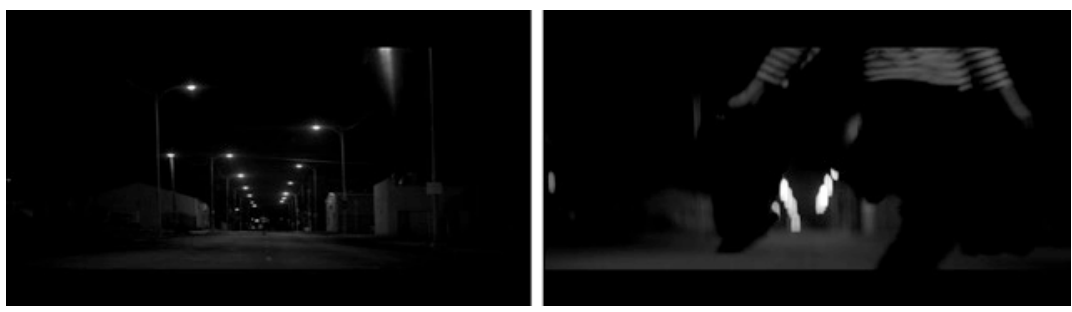

Fig. 7 and 8 A Girl Walks Home Alone at Night, "The vampire rides her skateboard," USA 2014 

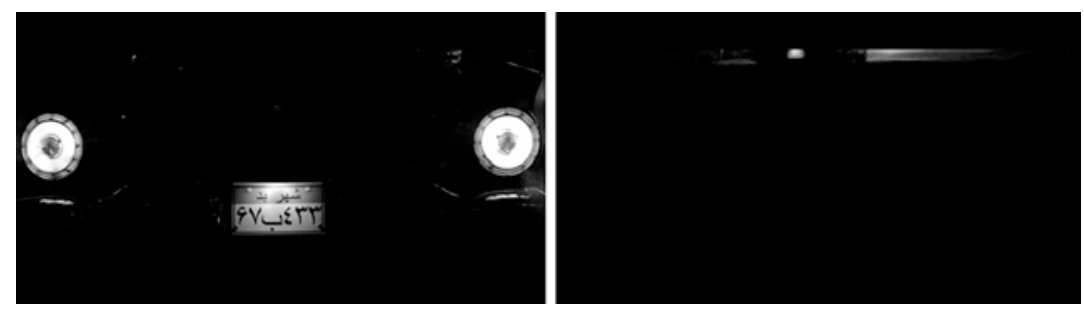

Fig. 9 and 10 A Girl Walks Home Alone at Night, "License plate and driving off," USA 2014

Alone at Night merges Iran and the Unites States and reimagines diaspora as a phenomenon where the frontier is not just extended but disappears entirely.

Based on the theoretical foundation that genre structures in the production and circulation of cultural artifacts are just as effective as the various approaches to using and analyzing media, Ivo Ritzer and Peter W. Schulze describe genre as a non-hermetic category: "genres cannot be understood as closed systems, but only as processes of systematization. They are always in flux and undergo changes" (2013, p. 15). Accordingly, as an open-ended concept, genre is especially useful for expressing the uncertainty and distance from (cultural) essentialism that are inherent to postdiaspora films: "genres do not resemble each other because they have a common feature, but because they share multiple properties. Therefore, they cannot be designated essentialistically" (Ritzer and Schulze 2013, p. 10). Edward Said famously wrote: "All cultures are involved in one another; none is single and pure, all are hybrid, heterogeneous, extraordinarily differentiated and unmonolithic" (1993, p. xxv). The flexible motion and discarding of clear designations are symptomatic of the similarities between genre and postdiaspora. The frontier no longer exists, space has long been conquered, and cultural and ethnical designations are no longer recognizable as simple hybrid forms.

\section{Conclusion: "Postdiaspora is an Emancipatory Move"}

The example of A Girl Walks Home Alone at Night analyzed above must be seen as an advancement of pre-existing diasporic spaces, which make cultural and cinematic attributions increasingly impossible. I would like to use the term "postdiaspora film," as a variety of what Jeffrey Sconce called "smart cinema": 
While previous forms of art cinema concentrated on formal experimentation with film style and narrative structure as a means of critiquing the codes of "bourgeois realism" and/or "bourgeois society," the new smart cinema has for the most part re-embraced classical narrative strategies, instead experimenting with tone (2002, p. 352; emphasis in original).

His concept functions as an umbrella term for a multitude of aesthetic and narrative forms, each of which is an expression of an individual handwriting. The postdiaspora film is thus an intelligent cinema that not only represents and depicts cultural differences, but may be taken as the premise for overcoming them:

Postdiaspora is an emancipatory move, refuting not the connection with one's place of origin, but rather one's unequal status vis-à-vis homelanders and hostlanders. Furthermore, postdiaspora is the struggle to overcome an imposed status position based on place of origin. Postdiaspora does not mean marginalization in the way diaspora does (Laguerre 2017, p. 22).

Using hybridized cultural and generic elements, Shahr-i Bad consists of multilayered intercultural spaces and thus opens up a field of plural potentialities. As a cinematic-hybrid space, Shahr-i Bad appears in such a way that the genre elements are used as cinematic means to create a genre-space that allows complex cultural exchange processes to be observed and analyzed on the basis of cross-spatial cinematic elements. Shahr-i Bad is a cinematic space in which several spatial dimensions, which are actually contradictory and mutually incompatible, are juxtaposed in one filmic-hybrid space. The unifying force prevails over the separating force in dissimilar constellations. Diaspora is not a culturally hermetic space, and neither is film. Thus the cinematic space becomes a media-space through the interrelation of different cultural elements. The flexible movement of relating and withdrawing clear attributions is symptomatic of the postdiaspora. This re-configuration of Shahr-i Bad's postdiaspora filmic space is based on revising genre elements from vampire and western film genres. The frontier no longer exists, the space has already been conquered, and cultural and ethnic attributions are no longer recognizable as hybrid forms. Instead, they are now cinematic media-spaces conceived less as transitions or passages than as places of residence. A Girl Walks Home Alone at Night thus joins the ranks of filmmaking that "survives (and at times thrives) at the symbolic and material intersection of 'Hollywood,' the 'indie' scene, and the vestiges of what cinephiles used to call 'art' films" (Sconce 2002, p. 351). As a filmic-hybrid space, it engages in cinematic transformation processes that go beyond its own re-configurations, thus allowing conclusions about general cultural transformations of postdiaspora and postdiaspora filmic spaces as they express mobile and flexible intersections and collaborations, which in turn stimulate further connections. 


\section{Endnotes}

1. This chapter is based on research conducted for my $\mathrm{PhD}$ thesis between 2013 and 2018 at the Philipps-University of Marburg, which has been published as a monograph under the title: Medienraum Diaspora. Verortungen zeitgenössischer iranischer Diasporafilme. Wiesbaden: Springer, 2019. Available open access here: https://link.springer.com/content/ pdf/10.1007\%2F978-3-658-24606-8.pdf.

2. Q\&A Hosted by Roger Corman at the Hammer Museum (Part of MoMa Contender's Series). Amirpour, Ana Lily, Reg. A girl walks home alone at night. Inc. Kino Lorber, 2015. DVD Extras.

3. Ibid.

4. Ibid.

\section{References}

Bauböck, Rainer (ed.). 2010. Diaspora and transnationalism: Concepts, theories and methods. Amsterdam: Amsterdam University Press.

Bourdieu, P. 1983. The field of cultural production, or: The economic world reversed. Poetics 12: 311-356.

Brah, Avtar. 1996. Cartographies of Diaspora: Contesting identities. London: Routledge.

Dabashi, Hamid. 2009. Post-Orientalism: Knowledge and power in time of terror. New Brunswick: Transaction Publishers.

Dufoix, Stephane. 2008. Diasporas. Berkeley: University of California Press.

Elahi, B., and P.M. Karim. 2011. Introduction: Iranian Diaspora. Comparative Studies of South Asia, Africa and the Middle East 31 (2): 381-387.

Hall, Stuart. 2007. Old and new identities, old and new Ethnicities. In Culture, globalization and the world-system: Contemporary conditions for the representation of identity, ed. Anthony D. King, 41-68. Minneapolis: University of Minnesota Press.

Laguerre, Michel. 2017. The Postdiaspora condition: Crossborder social protection, transnational schooling, and extraterritorial human security. London: Palgrave Macmillan.

Marks, Laura U. 2000. The skin of the film: Intercultural cinema, embodiment, and the senses. Durham: Duke University Press.

Mostofi, N. 2003. Who we are: The Perplexity of Iranian-American Identity. The Sociological Quarterly 44 (4): 681-703.

Naficy, Hamid. 2001. An accented cinema: Exilic and diasporic filmmaking. Princeton: Princeton University Press.

Naficy, Hamid. 2012. A social history of Iranian cinema: Volume 4: The globalizing era, 1984-2010. Durham: Duke University Press.

Public Affairs Alliance of Iranian Americans (PAAIA). 2014. Iranian Americans: Immigration and Assimilation. https://www.paaia.org/CMS/Data/Sites/1/pdfs/iranian-americans--immigration-and-assimilation.pdf. Accessed: 1 July 2019. 
„Q\&A“. Hosted by Roger Corman at the Hammer Museum (Part of MoMa Contender's Series). A Girl Walks Home Alone at Night. Dr. Ana Lily Amirpour. Inc. Kino Lorber, 2015. DVD Extras.

Raji, Sanaz. 2010. The Iranian Diaspora in the West. In Diasporas: Concepts, intersections, identities, ed. K. Knott and S. McLoughlin, 193-197. London: Zed Books.

Ritzer, I., and P.W. Schulze (eds.). 2013. Genre Hybridisation: Global Cinematic Flows. Marburg: Schüren.

Said, Edward W. 1993. Culture and imperialism. New York: Vintage.

Sayyad, Parviz, and Hamid Dabashi. 1993. Parviz Sayyad's Theater of diaspora: Two plays, the ass and the Rex Cinema trial. Costa Mesa: Mazda Publishers.

Sconce, J. 2002. Irony, Nihilism and the New American 'Smart' Film. Screen 43 (4): 349369.

Streck, Bernhard. 2000. Wörterbuch der Ethnologie. Wuppertal: Peter Hammer.

Tölölyan, Khachig. 2012. Diaspora studies: Past, present and promise. Working Paper 55.

Vahabi, Nader. 2012. Atlas de la diaspora iranienne. Paris: Ed. Karthala.

Alena Strohmaier is postdoctoral researcher and project leader of the research project "'But I'm not filming! I'm just doing a bit of video...' Cinematic appropriation processes of protest videos 2009-11 in the Middle East and North Africa" (2019-2023; funded by the German Federal Ministry of Education and Research) at Philipps-Universität Marburg (Germany). Prior, she was the academic coordinator of the research network "Re-Configurations" and managing editor of META Journal. Middle East - Topics \& Arguments (both Center for Near and Middle Eastern Studies). Her main areas of research are diaspora film, media and migration, digital archives, and video activism.

Open Access This chapter is licensed under the terms of the Creative Commons Attribution 4.0 International License (http://creativecommons.org/licenses/by/4.0/), which permits use, sharing, adaptation, distribution and reproduction in any medium or format, as long as you give appropriate credit to the original author(s) and the source, provide a link to the Creative Commons license and indicate if changes were made.

The images or other third party material in this chapter are included in the chapter's Creative Commons license, unless indicated otherwise in a credit line to the material. If material is not included in the chapter's Creative Commons license and your intended use is not permitted by statutory regulation or exceeds the permitted use, you will need to obtain permission directly from the copyright holder.

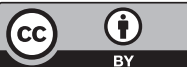

